DOI: 10.20472/IAC.2019.048.021

TAKAYASU ITO

Meiji University, Scool of Commerce, Japan

\title{
MONETARY POLICY EXPECTATIONS AND MONEY MARKET IN JAPAN : ANALYSIS OF NON-TRADITIONAL MONETARY POLICY REGIMES
}

\begin{abstract}
:
When the Bank of Japan (BOJ) adopts interest rate targeting under a comprehensive easing policy, the yield curve up to 12 months in the Japanese money market is driven by a single trend. It is caused by monetary policy expectations. The regime of interest rate targeting gives a sense of comfort to market participants that the regular transmission mechanism works in the yield curve of the money market. Thus, monetary policy expectations are fully transmitted to the yield curve end. On the other hand, monetary policy expectations are not fully transmitted to the yield curve end under either the quantitative and qualitative easing policy or the negative easing policy. The quantitative and qualitative easing policy and the negative interest rate policy paralyze the market function in the short-term money market. Central bankers should always keep it in mind that the transmission of interest rates along the yield curve is an integral part of the mechanism through which monetary policy affects the economy.
\end{abstract}

\section{Keywords:}

Monetary Policy Expectations, Money Market, Non-traditional Monetary Policy

JEL Classification: E40, E58, G10 